\title{
Statyba
}

\section{ACADEMICIAN ALEKSANDRAS ČYRAS AS THE PIONEER OF OPTIMIZATIONAL STRUCTURAL MECHANICS IN LITHUANIA}

\section{J. Atkočiūnas \& A. Krutinis}

To cite this article: J. Atkočiūnas \& A. Krutinis (1997) ACADEMICIAN ALEKSANDRAS ČYRAS AS THE PIONEER OF OPTIMIZATIONAL STRUCTURAL MECHANICS IN LITHUANIA, Statyba, 3:9, 6-10, DOI: $10.1080 / 13921525.1997 .10531665$

To link to this article: https://doi.org/10.1080/13921525.1997.10531665

曲 Published online: 26 Jul 2012.

Submit your article to this journal $2 \pi$

Џ Article views: 59 


\title{
ACADEMICIAN ALEKSANDRAS ČYRAS AS THE PIONEER OF OPTIMIZATIONAL STRUCTURAL MECHANICS IN LITHUANIA
}

\author{
J. Atkočiūnas, A. Krutinis
}

Prof. A.Čyras was born on March 15, 1927 in a picturesque Lithuanian locality, Merkinè. Here he finished secondary school. In 1950 he graduated with honours from the Building Faculty of Kaunas Vytautas the Great University and became Diploma civil engineer. As a capable graduate he continued his studies at the University as a Doctoral student and in 1954 defended his Doctoral thesis. His subsequent research, educational and administrative activities are connected with the departments of structural mechanics at Kaunas Polytechnical Institute (KPI) and Vilnius Civil Engineering Institute (VISI), with the administration of Vilnius subdivision of KPI as principle officer (Dean, Vice-Rector) in 1960-69. Prof. A.Cyras pioneered the establishment of the first higher technical school in Vilnius, namely VISI, in 1969. He was the first Rector of VISI and held Rector's position for many years.

The beginnings of mechanics as a science are closely connected with the old Vilnius University founded in 1579. During the first two centuries of the existence of the University mechanics was taught as part of physics. In 1780 the Department of Applied Mechanics was established by the order of Rector Počobut. Among the lectures delivered by its staff there was a special course on the mechanics of solids and liquids. Howewer, mechanics could be studied and developed during this period, especially after closing the University in 1832 , only by individuals. The engineering and research activities of the University graduates N.Jastržembskis (1808-74) and S.Kerbedis (1810-99) should be mentioned. The first of them compiled in 1837 "Course of practical mechanics" ( 2 vols) in Russian. It was the first manual at higher schools of Eastern Europe for studies of practical mechanics. This publication became a precedent for further development of mechanical investigations.

During the pre-war years of independent Republic of Lithuania the development of mechanics was connected with Kaunas Vytautas the Great University founded in 1922. The Department of Structural Mechanics was established at the Technical Faculty in the same year. Associated Professor Kazimieras Vasiliauskas (1879-1957) was appointed head of the Department. For a long time, even up to 1950, his articles (twelwe in number) published in journals "Technika" and "Technische Mechanik" (in Kaunas and Stockholm) were probably the only works in Lithuanian on problems of structural mechanics. A study guide "The fundamentals of structural statics" (1953) had a considerable influence on the development of structural mechanics in Lithuania.

The 1960's are of great importance for structural mechanics in its broad sense: the KPI gains strength in Kaunas and enlarges its activities in Vilnius under the guidance of A.Čyras. The achievements of Kaunas scientists such as Prof. Dr. KVasiliauskas, his disciples J.Baušys, A.Čyras, B.Garmus, J.Slavėnas etc. should be mentioned. Some distinguished research trends investigating solid deformable bodies have been developed at the Department of Structural Mechanics of KPI and they allowed to establish two separate independent departments: Dept. of Strength of (heads: Assoc. Prof. S.Vasauskas, prof. J.Baušys, prof. A.Žiliukas) and Dept. of Structural Mechanics (head Assoc. Prof. V.Klimavičius, 1910-82). The latter department is known for its theoretical and experimental trends investigating the constructions on elastic footings (V.Klimavičius, V.Gakas, A.Krutinis, A.Senuta, J.Žukas etc.). Important research was 
performed when investigating in structural dynamics and stability (B.Garmus, P.Baublys, I.Cypinas, M.Remišauskas, 1907-85, etc.). At the Dept. of Structural Mechanics (KPI) under the guidance of prof. V.Klimavičius, electronic computation techniques and matrix calculation elements were introduced for studies and research.

In 1960 the research centre of structural mechanics moves to Vilnius, to KPI subdivision, which was managed by an energetic investigator, a disciple of Academician $\mathrm{K}$. Vasiliauskas, the pioneer of optimizational structural mechanics Assoc. Prof. A. Čyras. Here, under the conditions of increased application of electronic computational techniques, new computing methods of structural mechanics were introduced. Classical computational methods of low efficiency applied for investigating complicated structures and outward factors were substituted by numerical methods able to formulate and solve the problems of calculating structures which could not be solved by other methods (physical and geometric non-linearity, optimization problems etc.) The investigations performed under the supervision of A.Cyras can be characterized by a large application of mathematical programming theory to the solid deformable body mechanics. Such a direction permitted to analise the problem of structural optimization by dual (static and kinematic) formulations of problems. By using the duality theory the properties of mathematical models were revealed and proofs of many theorems presented which were absent in the world scientific literature. In 1965 Assist. Prof. A.Čyras maintained his Doctor's of technical sciences thesis "Mathematical programming methods for calculating elastic-plastic onedimensional systems". The diverse activities of A.Čyras gained also a large international reputation. But it was a little later, when the school of A.Cyras was enlarged by a group of talented scientists: R.Baronas, A.Borkowski, A.Čižas, H.Gilys, V.Zakarevičius, etc. At first they analysed from different points of view the problems of elastic-plastic footings, including the optimization of plastic bar systems (beams, frames, trusses). A considerable experience of problem formulation and solution having been accumulated, the calculation of continual systems (plates, shells) under various factors and conditions was started. The problems of stability were discussed in A. Krutinis', A.Senuta's, P.Baublys', L.Lindišas' works. The practical application of mathematical programming needed an intensive development of new algorithms and computer programs. A considerable contribution was done by young representatives of Vilnius school of mechanics: J.Nagevičius, R.Karkauskas, J.Atkočiūnas, S.Kalanta, S.Mažuolis (1934-89), P.Čyras, V.Dulmanas, K.Vislavičius, R.Kačianauskas, V.Skaržauskas, L.Rimkus, L.Čiupaila, A.Daniūnas, N.Žukas, R.Baušys and the disciples of Prof. A.Čižas (his Doctor's Habil thesis in 1974): V.Kamaitis, S.Stupakas, M.Šukšta, A.Komka, J.Medzvieckas, etc. [1]. The synthesis of hinge-bar systems using computers was discussed by Prof. D.Maciulevičius and his disciples A.Čiučelis, A.Kuzmickas, R.Nogis, P.Baradokas, R.Belevičius, R.Kutas etc. The common things uniting the above-mentioned research groups were the investigation goal (optimization) and methods (mathematical programming) [1].

In the period of 1967-96 Prof. A.Cyras compiled over 180 articles, published 8 monographs [2]-[9], three of them abroad in English. His first monograph [2] is an example of successful foundation of a new research trend, namely the application of mathematical programming to structural optimization. The author of the book points out that the static computation of elastic discrete systems is a completely investigated area of structural mechanics. The idea was expressed by a correct canonic formulation of such problems which allowed to rearrange the problem and consider it as the solution of linear algebraic equations system. Matrix computation and electronic technique helped it. According to the monograph, the development of computational methods of elastoplastic structures has fallen behind the modern applied mathematics and computational techniques and was not able to use its possibilities. The first monograph by A.Čyras has changed the situation completely in this area. The general mathematical models of optimization problems were systematized in A.Čyras monographs [3], [5]-[9] and used as a basis, as previously mentioned, for developing methods, algorithms, 
computer programs for optimization problems of particular structures [4]. The development of elastic solidifying body optimization theory [3], [9] and stochastic modelling application can be considered as an important trend in Prof. A.Čyras research. In monograph [8] published in English, Prof. A.Cyras generalized his long-term investigations in dissipative system analysis and optimization and now ranks as a prominent scientist in this field of research. Thanks to AČyras monographs the achievements of Lithuanian researchers in optimization theory using methods of mathematical programming are known and recognized in Britain, Italy, USA, Poland, former USSR, Germany etc.

During Academician A.Čyras' administration of VISI (since 1990 renamed Vilnius Technical University), some principal trends of investigating solid deformable body mechanics have appeared (supervisors Academician A.Kudzys, Prof. D.Maciulevičius, Prof. A.Čižas, Prof. R.Belevičius [10]). In on of them, namely "Analysis and optimization stressstrain state in elastic-plastic structures", the staff of Dept. of Structural Mechanics at Vilnius Gediminas Technical University was engaged (head of the Dept. Assoc. Prof. A. Krutinis). In this trend the following problems should be mentioned: elastoplastic system optimization under cyclic loading (Assoc. Prof. J. Atkočiūnas, [11]); finite element method in the optimization theory (Assoc. Prof. S.Kalanta, Assoc. Prof. R.Karkauskas); analysis of elastoplastic systems (Assoc. Prof. J.Nagevičius, L.Rimkus, V.Skaržauskas, A.Norkus); optimization theory and methods of deformable footing (Assoc. Prof. A.Krutinis); mathematical models of plastic solidifying body (Assoc. Prof. R.Fliotovienè). For a long time at the Dept. of Structural Mechanics a special Laboratory for Structural Mechanics operated (1969-91). Under the supervision of AČyras, 27 Doctor's Habil theses have been maintained; his 5 disciples have become Doctors Habil:: D.Maciulevičius (1969), A.Čižas (1974), A.Borkowski (1978, [12]), R.Kačianauskas (1996,[13]), J.Atkočiūnas (1996, [11]).

Under the guidance of Academician AČyras some international conferences took place in Vilnius: "Optimization and reliability problems in structural mechanics" (1975, 1979, 1983, 1988), “New building materials, constructions and technologies" (from 1991; section "Optimization of structures and new calculation methods"). Prof. A.Čyras is member of editorial boards of some international journals, including "Mechanics research communications" (USA), "Applied mechanics" (Ukraine), "Structural mechanics and structures calculation" (Russia). Also he was the founder and editor-in-chief of "Journal of Lithuanian mechanics" (1967-94). He is member of Polish society of theoretical and applied mechanics (1982), foreign member of Russian national committee of theoretical and applied mechanics (1985). Besides, Prof. A.Cyras is member of scientific committees of many international conferences in Waterloo (Canada), Praha, Warsaw, Weimar, Moscow. In 1974 he was invited to deliver lectures in Rome, Milan universities and International centre of mechanics in Udine (Italy) [5].

For services in educating building engineers Prof. AČyras was awarded the title of Lithuanian Merited Builder (1963) and for his scientific achievements the title of Lithuanian Merited Researcher was conferred on him (1979). In 1969 he was awarded the famous prize by B.Galerkin. In 1980 Prof. AČyras became corresponding member and in 1994 full member of Lithuanian Academy of Sciences. Since 1994 he is a foreign member of Polish Academy of Sciences, since 1985 - Doctor honoris causa of Weimar Higher school of Architecture and Civil Engineering. In 1976, 1993 he received another reward, Lithuanian National Prize for research.

Prof. A.Čyras is an active propagator of new scientific ideas among students, future engineers. People who could attend his lectures speak about his distinct pedagogical talent. Unfortunately, intensive administrative and research activities, frequent trips did not allow to deliver lectures continuously for students. But we highly appreciate his frequent question, expressing his pedagogical anxiety: what things are the most urgent for students? What are we to teach them? Therefore due to Academician A.Cyras' initiative and persistency the VISI was successfully orientated to a large application of computers to educational purposes. When Rector, A.Čyras supervised rearranging syllabuses of mechanical courses and teaching methods. He has compiled 
and published modern study guides for Bachelors, Masters and Doctoral students [14-17]. The staff of Dept. of Structural Mechanics worked intensively when applying computerized methods in teaching structural mechanics. In 1984-94, when performing the work "Development of computerized teaching in structural mechanics", four manuals were published, many computer programs compiled, over 20 study guides prepared. In 1993 a group of researchers from Dept. of Structural Mechanics, including A.Cyras (scientific supervisor), R. Karkauskas, A. Krutinis, J.Atkočiūnas, S.Kalanta and J.Nagevičius, for a thoroughly compiled set of computerized manuals was awarded Lithuanian National Prize. Thus the beginnings of structural mechanics developed in the 19th century by N.Jastržembskis, S.Kerbedis thanks to A.Cyras efforts have grown up into a recognized Vilnius school of modern structural mechanics.

In 1996 the Rector's Board of Vilnius Gediminas Technical University for great services to this higher school awarded A.Čyras the Medal. In the same year for great services to Lithuania Academician A.Cyras was also awarded the 3-rd Order of Lithuanian Grand Duke Gediminas.

\section{Literatūra}

1. A.Čižas. Optimizacinès konstrukcijų mechanikos raida Vilniuje // Lietuvos mokslas. Vilnius, 1996, p. 120-122.

2. А.чирас. Методы линейного программирования при расчете упруго-пластических систем. Л.: Стройиздат, 1969. 199 c.

3. А.Чирас. Теория оптимизации в предельном анализе твердого деформируемого тела. Вильнюс: Минтис, 1971. $124 \mathrm{c}$.

4. А.ирас, А.Боркаускас, Р.Каркаускас. Теория и методы оптимизации упруго-пластических систем. Л.: Стройиздат, 1974. $280 \mathrm{c}$.

5. A.Čyras. Optimization theory in the design of elastoplastic structures // Structural optimization: CISM courses and lectures, Nr. 237. Berlin: Springer-Verlag, 1975, p. 81-150.

6. A.Cyras. Optimization problems in theory plasticity // Duality and complementarity in mechanics of solids. Wroclaw, 1979, p. 95-172.

7. А.Чирас. Математические модели анализа и оптимизации упруго-пластических систем. Вильнюс: Мокслас, $1982.112 \mathrm{c}$.

8. A.Cyras. Mathematical models for the analysis and optimization of elastoplastic structures. Chichester: Ellis Horwood Limited, 1983. $121 \mathrm{p}$.

9. А पирас, Р.Флетовене. Теория затвердевания. Вильнос: Техника, 1995. 75 с.
10. R.Belevičius. Computer Algebra in finite element method. Vilnius: Technika, 1994. $183 \mathrm{p}$.

11. Ю.Аткочюнас. Расчет упругопластических систем при повторных нагружениях. Вильнюс: Издательство науки и энщиклопедий, 1994. $148 \mathrm{c}$.

12. A.Borkowski. Statyczna analyza ukladow prętowych $w$ zakresach sprężystym i plastycznym. Warszawa Poznań: PWN, 1985. $200 \mathrm{~s}$.

13. R.Kačianauskas. Computer methods in multilevel modelling of beams and shells. Vilnius: Technika, 1995. $395 \mathrm{p}$.

14. А.Чирас. Строительная механика. Москва: Стройиздат, 1989. $256 \mathrm{c}$.

15. A.Cyras. Statybinè mechanika. Vilnius: Mokslas, 1990. $448 \mathrm{p}$.

16. Р.Каркаускас, А.Крутинис, Ю.Аткочюнас, С.Каланта, Ю.Нагявичюс. Строительная механика. Программы и решения задач на ЭВМ / Под общей редакцией ахадемика Литвы А.А.Чираса. Москва: Стройиздат, 1990. $360 \mathrm{c.}$

17. R.Karkauskas, A.Krutinis, J.Atkočiūnas, S.Kalanta, J.Nagevičius. Statybinès mechanikos uždaviniu sprendimas kompiuteriais. Vilnius: Mokslo ir enciklopediju leidykla, 1995. 264 p.

\section{AKADEMIKAS ALEKSANDRAS ČYRAS - OPTIMIZACINĖS STATYBINÉS MECHANIKOS LIETUVOJE PRADININKAS}

\section{J. Atkočiūnas, A Krutinis}

S a n t r a u k a

Straipsnyje pateikiama akademiko Aleksandro Cyro (g. $192703 \quad 15$ Merkinejje) mokslinès, kūrybinès ir pedagoginès veiklos apžvalga. A.Čyras $1950 \mathrm{~m}$. baigè Kauno Vytauto Didžiojo universiteto Statybos fakultetą. 1954 ir 1965 metais apgyne technikos moksly kandidato ir habilituoto daktaro disertacijas. Pirmosios Vilniuje aukštosios techniškosios mokyklos - Vilniaus inžinerinio statybos instituto (VISI) - jkūrimo 1969 metais iniciatorius. Pirmasis ir ilgametis VISI rektorius (1969-1990). Nuo 1985 metu - Lietuvos mokslų akademijos tikrasis narys. $1994 \mathrm{~m}$. išrenkamas Lenkijos MA užsienio nariu. Pagrindine moksliniu tyrimy kryptis - tampriuju-plastiniu sistemy optimizacijos teorija ir metodai, is ju ir taikant matematini programavimą. Vadovaujant prof. A.Cyrui Vilniuje periodiškai vyko optimizacijos ir patikimumo statybinejje mechanikoje problemų tarptautinès konferencijos. Skaitytos paskaitos JAV, Italijoje, Kanadoje, Vokietijoje ir kitose šalyse. Vadovaujant akademikui A.Cyrui 27 jo mokiniai apgyne mokslo kandidaty, o penketas - ir habilituoty mokslo daktary disertacijas. Bibliografiniai duomenys: 8 monografijos (trys iš ju išleistos anglu kalba užsienyje), 4 vadovèliai, per 180 mokslinių straipsnių.

Moderniosios statybinès mechanikos mokslinès mokyklos pagrindèjas akademikas A.Cyras už nuopelnus Lietuvai 1996 metais apdovanotas Didžiojo Lietuvos kunigaikščio Gedimino 3-ojo laipsnio ordinu. 
Juozas ATKOČñ̄naS. Doctor Habil, Associate Professor. Department of Structural Mechanics. Vilnius Gediminas Technical University (VGTU), 11 Sauletekio Ave, LT. 2040 Vilnius, Lithuania. E-mail: Juozas.Atkočiūnas @st.vtu.lt

Civil engineer, 1967. Dr Eng (structural mechanics), 1973. Dr Habil (mechanics), 1996. Research visits: Institute of Mechanics of Armenian Academy of Sciences, Warsaw Politechnical Institute, Moscow Civil Engineering Institute. Research interests: structural and computational mechanics, applied mathematical programming, analysis and optimization of dissipative structures under repeatedvariable loading.
Antanas KRUTINIS. Doctor, Associate Professor, Head of Department of Structural Mechanics. Vilnius Gediminas Technical University (VGTU), 11 Saulétekio Ave, 2040 Vilnius, Lithuania.

In 1971 Dr degree (structural mechanics). Scientific visits: Moscow Civil Engineering Institute, Kiev Civil Engineering Institute, Weimar Higher School of Architecture and Civil Engineering. Research interests: analysis and optimization of elastic-plastic structures on deformable ground. 